\title{
Changes in soil carbon stocks under different agricultural management practices in North Sri Lanka
}

\author{
R.R. Ratnayake ${ }^{1 *}$, T. Kugendren ${ }^{2}$ and N. Gnanavelrajah ${ }^{2}$ \\ ${ }^{\prime}$ Institute of Fundamental Studies, Hantana Road, Kandy. \\ ${ }^{2}$ Department of Agricultural Chemistry, Faculty of Agriculture, University of Jaffna, Kilinochchi.
}

Revised: 20 May 2013; Accepted: 08 August 2013

\begin{abstract}
There is great potential of storing and improving carbon in tropical agricultural soils by applying ecologically sound management practices. In this study, soil carbon fractions and stocks under different agricultural management practices were studied in North Sri Lanka. Five land use types, namely, annual crop organic fertilizer only (A-OF), annual crop inorganic fertilizer only (A-IF), annual crop organic + inorganic fertilizer (A-O/IF), perennial crops (PC) and a home garden (HG), which use different tillage practices and fertilizer applications were selected. A home garden abandoned for 20 years (AHG) was included to study no tilled conditions. From the five land use types A-OF showed the highest soil organic carbon (SOC) fractions probably as a result of continuous supply of organic fertilizer for years. Conversely a lower SOC and other labile fractions were observed in A-IF probably due to greater decomposition of native soil organic matter under mineral fertilizer. Microbial biomass carbon (MBC) was significantly different among the treatments with the highest $(631 \mathrm{mg} / \mathrm{kg})$ in A-OF. AHG having the highest litter fall with zero tillage maintained the highest SOC content (68\%). Comparatively high water soluble C content $(0.055 / 0.57 \mathrm{mg} / \mathrm{kg})$ in both home gardens $(\mathrm{HG} / \mathrm{AHG})$ and $\mathrm{PC}(0.055 \mathrm{mg} / \mathrm{kg})$ could be possibly due to fresh residues returning to the soil whereas no residues return in annual crop sites. The potential stable carbon stock was the highest in AHG (15.40 t/ha) followed by A-OF (11.17 $\mathrm{t} / \mathrm{ha}$ ) compared to the other agricultural land uses. Active $\mathrm{C}$ was the highest in AHG (4.34 t/ha) followed by $3.98 \mathrm{t} / \mathrm{ha}$ in HG. A-IF recorded the lowest amount of active C $(1.73 \mathrm{t} / \mathrm{ha})$. Soil C stocks of annual crops can be improved compared to all other perennial land uses by using organic fertilizer application. Inorganic fertilizers in annual crops improve soil carbon storage only when combined with organic fertilizers.
\end{abstract}

Keywords: Agricultural land uses, inorganic fertilizer, organic fertilizer, soil carbon stocks, soil organic carbon, soil tillage.

\section{INTRODUCTION}

Although the basic processes of carbon sequestration in soils of tropical and temperate regions are similar, the sequestration rates are generally lower in the tropics due to the prevalence of high temperature and microbial activity throughout the year (Singh \& Ghoshal, 2007; Lal et al., 2007). However, the occurrence of a longgrowing season in the tropics will be an advantage for improving the $\mathrm{C}$ storage capacity of soil by applying various ecologically sound management options (Singh \& Ghoshal, 2007).

The carbon stored in cultivated soil has declined drastically because agricultural practices typically deplete soil $\mathrm{C}$ by removing major fractions of photosynthetically fixed $\mathrm{C}$ as harvest, and therefore returning only a small amount of plant litter to the soil (Singh \& Ghoshal, 2007). However appropriate land management can contribute significantly to soil $\mathrm{C}$ sequestration by manipulating the conditions to generate greater biological inputs of $\mathrm{C}$ than losses, because soil C stocks are mainly determined by $\mathrm{C}$ inputs and the decomposition rate (Poirier et al., 2008). Natural $\mathrm{C}$ inputs to soil in agroecosystems occur mainly by the incorporation of aboveground crop residues and the functions associated with root systems (Lal et al., 2007).

Several studies have shown that in agroecosystems both crop yield and soil $\mathrm{C}$ sequestration are generally influenced by tillage, fertilizer practices, residue management, irrigation and pesticide use (Vandenbygaart et al., 2003; Singh \& Ghoshal, 2007; Poirier et al., 2008). 
No till usually promotes $\mathrm{C}$ storage in the surface soil (Angers et al., 1997). Soil organic matter improves most of the physical, chemical and biological properties that favourably affect crop production. Hence, any measures taken to improve carbon sequestration in agricultural land-uses would yield benefits to the farmers (Lal et al., 2007).

In arable cropping systems, organic matter storage in soil is usually positively related to the $\mathrm{C}$ input, which includes aboveground residues and root biomass (Poirier et al., 2008). There are reports that $\mathrm{N}$ fertilization can increase soil organic carbon (SOC) storage (Campbell \& Zentner, 1993) by modifying the dynamics of soil decomposers (Park, 1976) and affecting $\mathrm{C}$ cycling in the soil. Recous et al. (1995) observed that the decomposition of corn residues was hindered when soil mineral $\mathrm{N}$ content was $<30 \mathrm{mg} \mathrm{N} \mathrm{kg}^{-1}$ but not $>60 \mathrm{mg} \mathrm{N} \mathrm{kg}^{-1}$.

Recent estimates have indicated wide variations in $\mathrm{C}$ sequestration under different land uses and recommended agricultural management practices throughout the world (Lal, 2008). Sequestration under different agricultural practices may approximate: zero/ reduced tillage $100-1000$, use of cover crops $50-$ 250 , manuring $50-150$, mixed farming $50-200$, and agroforestry $100-200 \mathrm{~kg} \mathrm{C}$ per ha per yr (Lal, 2008).

Quantifying the effects of management practices and their combinations on $\mathrm{C}$ sequestration is vital for improving the potential of farming systems to sequester $\mathrm{C}$. The present study was carried out to quantify and compare SOC fractions and available $\mathrm{C}$ stocks under different agricultural land uses and management practices in Sri Lanka with a long term objective of improving the soil $\mathrm{C}$ sequestration by applying different management options.

\section{METHODS AND MATERIALS}

\section{Study area}

The study was carried out on calcic red yellow latosol soil (Moormaan \& Panabokke, 1961) in the Jaffna District located in the Northern Province of the Dry Zone in Sri Lanka (5 $54^{\prime} \mathrm{N}-9^{\circ} 52^{\prime} \mathrm{N}$ latitude and $79^{\circ} 39^{\prime} \mathrm{E}-$ $81^{\circ} 53^{\prime}$ E longitude). Sampling locations were scattered in Divisional Secretariat Divisions of Kopay, Tellipalai and Chavakacheri. The average annual rainfall was $1000 \mathrm{~mm}$ and the mean temperature was $28^{\circ} \mathrm{C}$.

The 6 main land use types selected were: annual crop rotations with organic fertilizer only A-OF; inorganic fertilizer only A-IF; combined use of organic and inorganic fertilizer A-O/IF; a home garden HG; abandoned home garden AHG and perennial crop land PC (the continuous banana cultivation fields were considered as perennial crop lands) of the same soil type. Traditional home gardens of a few generations were taken as HG and no inorganic fertilizers have been used in these. The AHGs were similar but have been abandoned for 20

Table 1: Descriptive information of the field sites studied

\begin{tabular}{llllll}
\hline Field site & Current land-use & Fertilizer application & $\begin{array}{l}\text { Past land use } \\
\text { (10 years before })\end{array}$ & Method of vegetation & $\begin{array}{l}\text { Land } \\
\text { management } \\
\text { till/no till }\end{array}$ \\
\hline A-OF & $\begin{array}{l}\text { Annual crop } \\
\text { (chilli and onion } \\
\text { crop rotation) }\end{array}$ & $\begin{array}{l}\text { Organic fertilizer } \\
\text { only }\end{array}$ & $\begin{array}{l}\text { Annual crop } \\
\text { cultivation }\end{array}$ & $\begin{array}{l}\text { Crop rotation with } \\
\text { mono cropping }\end{array}$ & Till \\
A-IF & $\begin{array}{l}\text { Annual crop } \\
\text { (chilli and onion } \\
\text { crop rotation) }\end{array}$ & $\begin{array}{l}\text { Inorganic fertilizer } \\
\text { only }\end{array}$ & $\begin{array}{l}\text { Annual crop } \\
\text { cultivation }\end{array}$ & $\begin{array}{l}\text { Crop rotation with } \\
\text { mono cropping }\end{array}$ & Till \\
A-O/IF & $\begin{array}{l}\text { Annual crop } \\
\text { (chilli and onion } \\
\text { crop rotation) }\end{array}$ & $\begin{array}{l}\text { Combination of } \\
\text { organic and } \\
\text { inorganic fertilizer }\end{array}$ & $\begin{array}{l}\text { Annual crop } \\
\text { cultivation }\end{array}$ & $\begin{array}{l}\text { Crop rotation with } \\
\text { mono cropping }\end{array}$ & Till \\
PC & $\begin{array}{l}\text { Perennial crop } \\
\text { (Banana) }\end{array}$ & No fertilizer & Banana cultivation & Mono cropping & Till \\
HG & $\begin{array}{l}\text { Home garden } \\
\text { AHG }\end{array}$ & No fertilizer & Home garden & Mixed cropping & Till \\
\hline
\end{tabular}

Annual crop- organic fertilizer only (A-OF), annual crop- inorganic fertilizer only (A-IF), annual crop- organic/ inorganic both (A-O/IF), agricultural fields with perennial crops (PC), home garden (HG) and a home garden abandoned for 20 years (AHG) 
years. The common types of organic manure were cattle dung, green leaves (Gliricidia, Thespesia), and compost used in a regular manner (about $20-25 \mathrm{t} / \mathrm{ha}$ twice a year) for 10 years. The amount and the composition of the organic fertilizers used varied with the types of the crops cultivated during the 10 year period. On average $\mathrm{N}$ (urea), $\mathrm{P}_{2} \mathrm{O}_{5}$ (tripple super phosphate), $\mathrm{K}_{2} \mathrm{O}$ (muriate of potash) - 125,100,100 kg/ha, respectively have been

Table 2: Species composition in different land uses

\begin{tabular}{|c|c|c|}
\hline Land uses & Common name & Botanical name \\
\hline $\mathrm{PC}$ & $\begin{array}{l}\text { Banana varieties: Kappal, } \\
\text { Monthan (Sampal monthan, Vanni monthan), } \\
\text { Itharai (Local itharai, Colombo itharai), } \\
\text { Kathali (Vel kathali, Pachchai kathali) }\end{array}$ & Musa sapientum \\
\hline $\mathrm{AHG}$ & $\begin{array}{l}\text { Neem } \\
\text { Kalyana murunga } \\
\text { Ipil-Ipil } \\
\text { Mango } \\
\text { Woodapple } \\
\text { Tamarind } \\
\text { Palmyrah }\end{array}$ & $\begin{array}{l}\text { Azadirachta indica } \\
\text { Erythrina indica } \\
\text { Leucaena leucocephala } \\
\text { Mangifera indica } \\
\text { Limonia acidissima } \\
\text { Tamarindus indica } \\
\text { Borrasus flabellifer }\end{array}$ \\
\hline $\mathrm{HG}$ & $\begin{array}{l}\text { Chili } \\
\text { Tomato } \\
\text { Bitter gourd } \\
\text { Snake gourd } \\
\text { Brinjal } \\
\text { Banana } \\
\text { Bamboo } \\
\text { Cassava } \\
\text { Jumbu } \\
\text { Lemon } \\
\text { Pomegranate } \\
\text { Guava } \\
\text { Vallarai } \\
\text { Coconut } \\
\text { Mango } \\
\text { Betel } \\
\text { Jack } \\
\text { Curry leaves } \\
\text { Nelli } \\
\text { Papaw } \\
\text { Sessile plant } \\
\text { Sugarcane }\end{array}$ & $\begin{array}{l}\text { Capsicum annum } \\
\text { Lycopersicum esculentum } \\
\text { Momordica charantia } \\
\text { Trichosanthes cucumerina } \\
\text { Solonum melongena } \\
\text { Musa sapientum } \\
\text { Bambusa vulgaris } \\
\text { Manicot utlissima } \\
\text { Syzygium malaccensis } \\
\text { Citrus aurantifolia } \\
\text { Punica granatum } \\
\text { Psidium guajava } \\
\text { Centella asiatica } \\
\text { Cocos nucifera } \\
\text { Mangifera indica } \\
\text { Piper betel } \\
\text { Artocarpus heterophyllus } \\
\text { Murraya koenigii } \\
\text { Phyllanthus emblica } \\
\text { Carica papaya } \\
\text { Alternanthera sessilis } \\
\text { Saccharum officinarum }\end{array}$ \\
\hline A-IF & $\begin{array}{l}\text { Chili } \\
\text { Onion } \\
\text { Tobacco }\end{array}$ & $\begin{array}{l}\text { Capsicum annum } \\
\text { Allium cepa } \\
\text { Nicotiana tobacum }\end{array}$ \\
\hline $\mathrm{A}-\mathrm{OF}$ & $\begin{array}{l}\text { Tomato } \\
\text { Brinjal } \\
\text { Bitter gourd }\end{array}$ & $\begin{array}{l}\text { Lycopersicum esculentum } \\
\text { Solanum melongena } \\
\text { Momordica charantia }\end{array}$ \\
\hline $\mathrm{A}-\mathrm{O} / \mathrm{IF}$ & $\begin{array}{l}\text { Onion } \\
\text { Chili }\end{array}$ & $\begin{array}{l}\text { Allium cepa } \\
\text { Capsicum annum }\end{array}$ \\
\hline
\end{tabular}

Annual crop- organic fertilizer only (A-OF), annual crop- inorganic fertilizer only (A-IF), annual crop- organic/ inorganic both (A-O/IF), agricultural fields with perennial crops (PC), home garden (HG) and home garden abandoned for 20 years (AHG) 
incorporated to soil in A-IF twice a year for more than 10 years. Descriptive information of the field sites studied and the crops cultivated are given in Tables 1 and 2 .

\section{Soil sampling}

In each land use type $20 \mathrm{~m} \times 20 \mathrm{~m}$ area plots were demarcated. After removing the soil surface litter layer at random positions, soil core samples were collected from each plot at 2 depth levels $(0-15 \mathrm{~cm}$ and $15-$ $30 \mathrm{~cm})$. From each depth, 18 samples were collected. Two adjacent samples were pooled together to form 9 composite samples for each depth.

\section{Soil sample preparation and analysis}

All visible organic debris, stones, plant roots were removed and large soil aggregates were crushed. The samples were sieved using a $2 \mathrm{~mm}$ mesh sieve. Microbial biomass $\mathrm{C}$, moisture and soil $\mathrm{pH}$ were measured using fresh soil. The rest of the samples were air dried and ground to form a powder of $<0.15 \mathrm{~mm}$. Additional soil samples were taken from each site and analyzed for gravimetric water content and bulk density (Blake \& Hartge, 1986).

Microbial biomass carbon (MBC) and microbial biomass nitrogen were determined by using the chloroform fumigation and extraction method (Vance et al., 1987). After fumigation, microbial $\mathrm{C}$ and $\mathrm{N}$ were extracted using $0.5 \mathrm{M} \mathrm{K}_{2} \mathrm{SO}_{4}$ and quantified using the TOC analyzer (multi N/C 2100, Analytikjena, Germany). The samples were tested for total organic carbon using wet oxidation by acidified dichromate of organic carbon (Baker, 1976). The labile fractions of soil organic carbon are mainly from the active carbon pools, which were determined by the $\mathrm{KMnO}_{4}$ - oxidizable carbon estimation (Weil et al., 2003) and the water labile organic carbon estimation (Ghani et al., 2003).

\section{Statistical design and analysis}

The data were analyzed as a completely randomized design (CRD) analysis of variance (ANOVA), with 6 treatments and 3 replicates of each treatment. All comparisons were completed using SAS (SAS, 1999). The least significant difference (LSD) test was performed to determine treatment differences at the $\mathrm{p}<0.001$ level.

\section{RESULTS}

The soil $\mathrm{pH}$ varied between $6.66-8.21$ and the lowest and highest $\mathrm{pH}$ values were recorded in $\mathrm{A}-\mathrm{IF}$ and $\mathrm{PC}$ land uses, respectively. However the $\mathrm{pH}$ was not significantly different in these two land uses and home gardens. The $\mathrm{pH}$ of $\mathrm{A}-\mathrm{OF}$ and $\mathrm{AHG}$ were intermediate. The soil moisture content ranged from $6-16.75 \%$. However, there was no significant difference observed in moisture content among the different land uses. Soil bulk density values varied significantly among the different land uses studied $\left(1.42-1.82 \mathrm{~g} \mathrm{~cm}^{-3}\right)$ (Table 3 ). Bulk density was lowest in $\mathrm{A}-\mathrm{O} / \mathrm{IF}$ followed by A- OF. On the other hand, the highest bulk density was observed in A- IF followed by $\mathrm{HG}$. AHG and PC had intermediate values of bulk density.

MBC was significantly different among the treatments (Figure 1a). Among the agricultural land uses studied, although A-OF had the highest amount of $\mathrm{MBC}$, it was not significantly different compared to
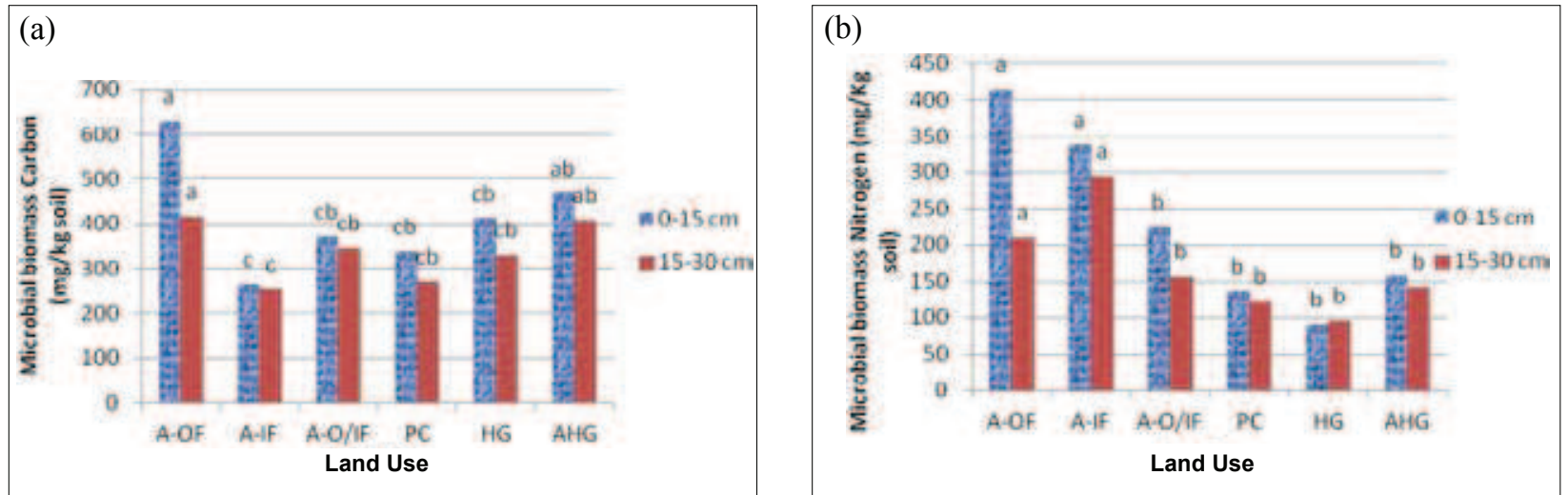

Figure 1: (a) Microbial biomass carbon ( $\mathrm{mg} / \mathrm{Kg}$ soil) in different land uses

(b) Microbial biomass nitrogen content in different land uses : annual crop- organic fertilizer only (A-OF), annual crop-inorganic fertilizer only (A-IF), annual crop- organic/ inorganic both (A-O/IF), agricultural fields with perennial crops (PC), home garden (HG) and home garden abandoned for 20 years (AHG)

Bars with the same letter are not significantly different at $5 \%$ probability level 


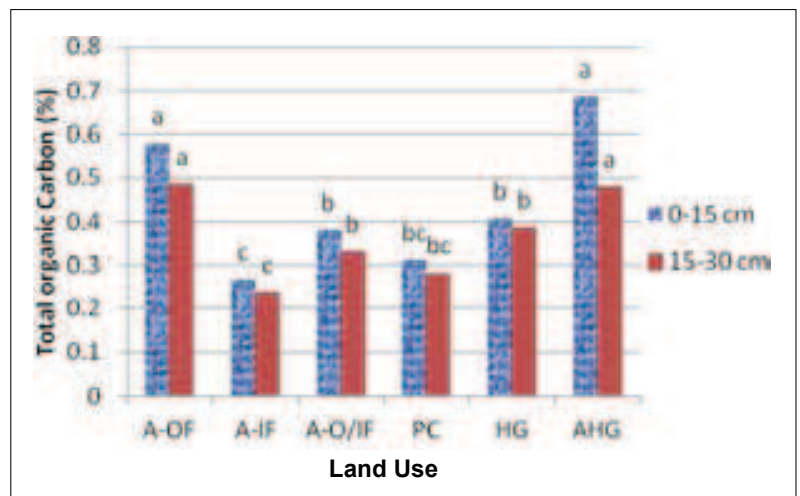

Figure 2: Total organic carbon content in different land uses: annual crop - organic fertilizer only (A-OF), annual crop - inorganic fertilizer only (A-IF), annual crop - organic/ inorganic both (A-O/IF), agricultural fields with perennial crops $(\mathrm{PC})$, home garden $(\mathrm{HG})$ and home garden abandoned for 20 years (AHG)

Bars with the same letter are not significantly different at $5 \%$ probability level

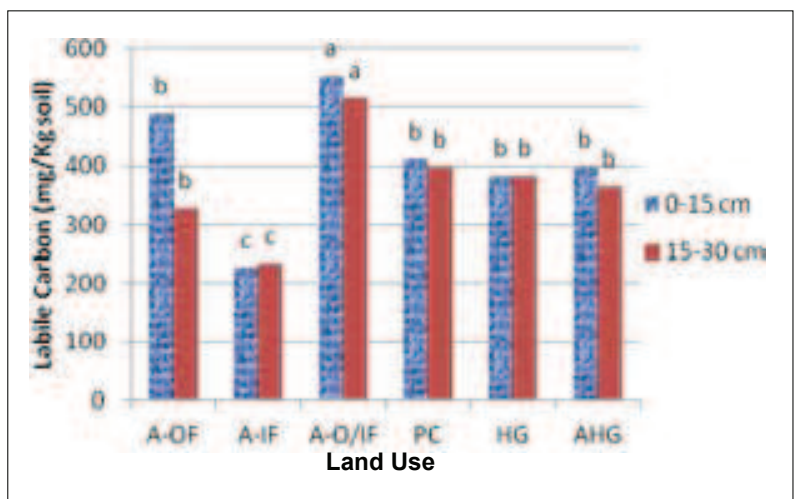

Figure 3: $\mathrm{KMnO}_{4}$ oxidizable carbon content in different land uses: annual crop - organic fertilizer only (A-OF), annual crop- inorganic fertilizer only (A-IF), annual crop - organic/ inorganic both (A$\mathrm{O} / \mathrm{IF}$ ), agricultural fields with perennial crops (PC), home garden (HG) and home garden abandoned for 20 years (AHG)

Bars with the same letter are not significantly different at $5 \%$ probability level

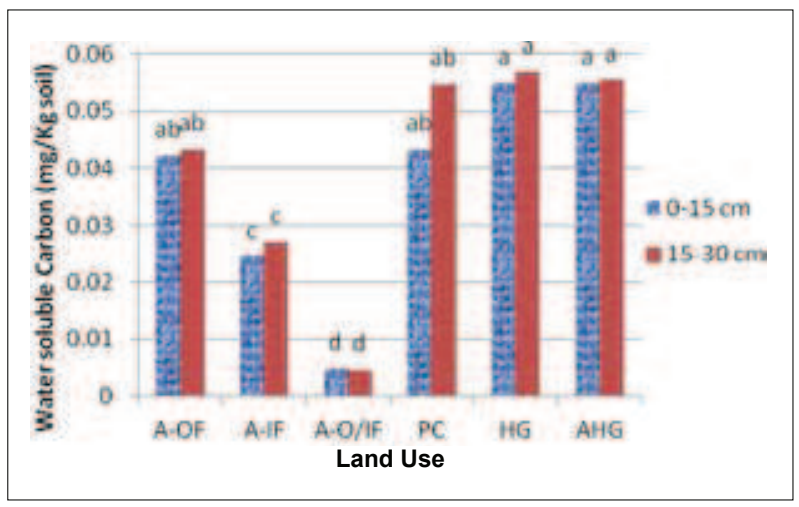

Figure 4: Water soluble carbon content in different land uses: annual croporganic fertilizer only (A-OF), annual crop - inorganic fertilizer only (A-IF), annual crop- organic/ inorganic both (A-O/IF), agricultural fields with perennial crops (PC), home garden (HG) and home garden abandoned for 20 years (AHG)

Bars with the same letter are not significantly different at 5\% probability level
Table 3: Soil pH, moisture content and bulk density of land uses

\begin{tabular}{llcc}
\hline Land uses & $\mathrm{pH}$ & $\begin{array}{c}\text { Moisture content } \\
(\%)\end{array}$ & Bulk density \\
\hline A-OF & $7.71^{\mathrm{ab}}$ & $16.75^{\mathrm{a}}$ & $1.6^{\mathrm{cb}}$ \\
A-IF & $6.66^{\mathrm{b}}$ & $7.68^{\mathrm{a}}$ & $1.82^{\mathrm{a}}$ \\
A-O/IF & $8.07^{\mathrm{a}}$ & $13.89^{\mathrm{a}}$ & $1.4^{\mathrm{c}}$ \\
PC & $8.21^{\mathrm{a}}$ & $7.01^{\mathrm{a}}$ & $1.71^{\mathrm{ab}}$ \\
HG & $7.83^{\mathrm{a}}$ & $7.26^{\mathrm{a}}$ & $1.8^{\mathrm{a}}$ \\
AHG & $7.40^{\mathrm{ab}}$ & $6.00^{\mathrm{a}}$ & $1.73^{\mathrm{ab}}$ \\
\hline
\end{tabular}

Annual crop - organic fertilizer only (A-OF), annual crop inorganic fertilizer only (A-IF), annual crop- organic/ inorganic both (A-O/IF), agricultural fields with perennial crops (PC), home garden $(\mathrm{HG})$ and home garden abandoned for 20 years (AHG)

AHG. PC, HG and A-O/IF did not show any significant differences in biomass $\mathrm{C}$ among them. A-OF and A-IF showed significantly high values of microbial biomass $\mathrm{N}$ compared to the other land uses, while the other land uses had comparable values of microbial biomass N (Figure 1b). However, depth-wise, there was no significant difference observed in either microbial biomass carbon or nitrogen.

AHG showed the highest SOC among all land use types, however A-OF did not have significant differences in SOC compared to AHG. A-OF and AHG showed a significant increase in SOC and soil C stocks compared to all other agricultural land use types (Figure 2, Table 4).

The labile $\mathrm{C}$ fraction of soil was significantly high in A-O/IF (Figure 3). A-IF had the lowest amount of labile carbon compared to the other land use types.

Home gardens (HG, AHG) had the highest water soluble carbon content (Figure 4), while the other agricultural land use types showed significantly lower water soluble carbon contents. A-O/IF showed the lowest water soluble carbon content.

The potential stable carbon was highest in AHG (15.40 t/ha) followed by A-OF (11.17 t/ha) (Table 4) compared to the other agricultural land uses. A-IF recorded the lowest amount of active $\mathrm{C}(1.73 \mathrm{t} / \mathrm{ha})$.

\section{DISCUSSION}

The highly reduced $\mathrm{pH}$ of A-IF is due to the acidifying effect of inorganic fertilizers and less buffer capacity of soils due to poor organic matter content of these land use types compared to the others. As the annually cropped lands are intensively managed with irrigation, A-OF had the highest moisture content added with higher content 
Table 4: Carbon stocks at various land uses

\begin{tabular}{lcccccc}
\hline Field site & $\begin{array}{c}\text { Total organic } \\
\text { carbon (t/ha) }\end{array}$ & $\begin{array}{c}\mathrm{KMnO}_{4} \text { oxidizable } \\
\text { carbon (t/ha) }\end{array}$ & $\begin{array}{c}\text { Microbial biomass } \\
\text { carbon (t/ha) }\end{array}$ & $\begin{array}{c}\text { Water soluble } \\
\text { carbon (t/ha) }\end{array}$ & $\begin{array}{c}\text { Active carbon } \\
(\mathrm{t} / \mathrm{ha})\end{array}$ & $\begin{array}{c}\text { Potential stable } \\
\text { carbon (t/ha) }\end{array}$ \\
\hline A-OF & 14.31 & 0.99 & 1.56 & 0.61 & 3.15 & 11.17 \\
A-IF & 6.64 & 0.96 & 0.66 & 0.12 & 1.73 & 4.91 \\
A-O/IF & 8.10 & 0.48 & 0.79 & 0.89 & 2.17 & 5.94 \\
PC & 8.11 & 1.07 & 0.88 & 1.12 & 3.07 & 5.04 \\
HG & 8.52 & 1.45 & 1.08 & 1.44 & 3.98 & 4.54 \\
AHG & 19.74 & 1.41 & 1.35 & 1.58 & 4.34 & 15.40 \\
\hline
\end{tabular}

Annual crop- organic fertilizer only (A-OF), Annual crop- inorganic fertilizer only (A-IF), Annual crop- organic/ inorganic both (A-O/IF), agricultural fields with perennial crops (PC), home garden (HG) and an abandoned home garden (AHG)

of organic matter. A-O/IF ranked second in moisture content for the same reason. In contrast, although AHG had the highest organic matter content, the soil had the lowest moisture content due to zero irrigation compared to the other land uses studied. However, these differences are not significant as the values show a high variability. The relatively similar lower bulk density values observed in A- O/IF and A-OF could be due to the effect of organic matter content and moisture content on aggregation of soil particles. Although AHG had the highest organic matter content the lowest moisture content would have limited the aggregation. The amount of organic matter added are similar in both treatments. However, the combined application of organic and inorganic fertilizers are effective in improving the soil bulk density as also reported by Hati et al. (2006) and Jinwei and Lianren (2011). This decrease in the bulk density in A-O/IF might be due to the increased root growth in the inorganic and organic fertilizer treated plots (Hati et al., 2006). Inorganic fertilizers could supply readily available phosphorus thereby enhancing the root growth. Enhanced root growth and improved organic matter content could have contributed to the lower bulk density.

The results suggest that applying high levels of mineral fertilizers lower the SOC and C stock, probably by stimulating residue decomposition as reported by Lal et al. (2005). Lowest SOC in A-IF is also attributed to an imbalance in fertilizer use and excessive tillage resulting in severe soil degradation (Lal et al., 2007).

As reported by Seneviratne et al. (2011), chemical fertilizers reduce the microbial biomass to a significant level while organic fertilizers increase it. This was reflected by the high $\mathrm{MBC}$ in $\mathrm{A}-\mathrm{OF}$ and the lowest MBC in A-IF. The amount of microbial biomass is generally the highest in undisturbed systems as observed in the abandoned home gardens and decline with increasing disturbances. Plant communities influence bacterial communities in soil via different pathways (Lamb et al., 2011). It was also shown that species richness has a significant direct effect on soil microbial community (Lamb et al., 2011).

The microbial biomass $\mathrm{N}$ values show a higher tendency for temporal fluctuations than microbial biomass C values (Brookes et al., 1985; Moore et al., 2000), because microorganisms differ more in $\mathrm{N}$ content than in their C content (Anderson \& Domsch, 1980; Jenkinson $\&$ Ladd, 1981). Therefore, small shifts in the structure of the microbial community can result in large changes in microbial biomass N (Campbell et al., 1991; Moore et al., 2000). Thus the trends shown in the microbial biomass $\mathrm{C}$ were not shown in the microbial biomass $\mathrm{N}$. Also the long-term application of $\mathrm{N}$ fertilizers may lead to changes in the structure of soil microbial communities in terms of promoting nitrifying populations and enhancing nitrification rates (Moore et al., 2000) as reflected by the high values of microbial biomass $\mathrm{N}$ in A-IF.

AHG having the highest litter fall with zero tillage maintained the highest SOC content. The structure and composition of soil in the abandoned home gardens have improved over years as they were left without human interventions for about 20 years allowing nutrient cycling and increasing soil organic carbon (Kumar, 2011). Comparatively high water soluble $C$ content in both home gardens (HG/ AHG) and PC could be possibly due to fresh residues returning to the soil, whereas no residues return in annual crop sites.

SOC and C stocks increased due to organic fertilizers as also reported by Sirinivasarao et al. (2012). Long-term addition of organic fertilizers have increased the content of 
SOC (Uchida et al., 2012) in A-OF. Experiments suggest that organic fertilizers usually favour the formation of soil aggregates and minimizes the potential for rapid oxidation of soil organic matter (Kumar, 2011). Water soluble carbon content in soil is generally low compared to the microbial biomass $\mathrm{C}$ and labile $\mathrm{C}$ fractions and accounts only for a small portion of the total organic carbon as also reported by Uchida et al. (2012). Water soluble carbon is the most mobile form in soil organic $\mathrm{C}$ fraction (Ghani et al., 2003) and can be rapidly utilized by soil microorganisms. It is reported that the amount of soil $\mathrm{C}$ extracted by using cold water is comparatively lower than the amount of $\mathrm{C}$ extracted by using hot water (Sparling et al., 1998; Ghani et al., 2003). However hot water extraction method was not used as hot water would extract a part of other fractions like $\mathrm{MBC}$ and $\mathrm{C}$ bound to soil enzymes (Sparling et al., 1998; Ghani et al., 2003).

In general, the top soil layers $(0-15 \mathrm{~cm})$ have a significantly higher amount of $\mathrm{C}$ when compared to deep layers $(15-30 \mathrm{~cm})$. However Poirier et al. (2008) have reported that there is a high $\mathrm{SOC}$ content in $15-30 \mathrm{~cm}$ layer of tilled soil. In contrast to these findings the present study showed no difference between the 2 layers, $0-15$ and $15-30 \mathrm{~cm}$. Although it is not significant, the top soil layers $(0-15 \mathrm{~cm})$ had a high SOC content and active carbon content probably due to the aboveground inputs and roots mechanically mixed in the surface layer.

It has been shown that crop species play an important role in soil C sequestration because their residues vary in litter quantity and quality affecting their turnover rates in the soil (Ratnayake et al., 2011). The major problem associated with mono - crop agricultural systems is crop removal during harvesting leading to depletion of carbon available for recycling in the systems. Surface soils in the no-till and organic systems had significantly greater concentrations of $\mathrm{C}$ than in the conventionally managed systems (Six et al., 2006; Pereira et al., 2012). Major factors determining the rate of carbon accumulation in these tropical soils will be the quality and the quantity of litter returning to soil and soil tillage (Lamb et al., 2011).

\section{CONCLUSION}

A-OF maintained the highest $\mathrm{C}$ stocks while A-IF maintained the lowest $\mathrm{C}$ stocks in the annual cropping systems studied. Organic fertilizer had a pronounced effect on SOC and carbon stocks in annual cropping systems. Mineral fertilizer lowers SOC and C stocks in tropical crop lands by stimulating residue decomposition. However, high $\mathrm{C}$ stocks under A-O/IF shows that inorganic fertilizer in combination with organic fertilizer can improve $\mathrm{C}$ storage capacity of annual crops. Increased $\mathrm{SOC}$ and $\mathrm{C}$ stocks in AHG provide evidence to understand how much $\mathrm{C}$ can be gained under no till conditions.

\section{Acknowledgement}

The authors acknowledge the assistance given by the farmers in the Divisional Secretariats of Kopay, Tellipalai and Chavakacheri. Thanks are also due to Ms Kumuduni Karunaratne for assistance in chemical analysis and Mr M.A. Lal for help with soil sampling and sample preparation.

\section{REFERENCES}

1. Anderson J.P.E. \& Domsch K.H. (1980). Quantities of plant nutrients in the microbial biomass of selected soils. Soil Science 130: 211 - 216.

DOI: http://dx.doi.org/10.1097/00010694-19801000000008

2. Angers D.A., Bolinder M.A., Carter M.R., Gregorich E.G., Drury C.F., Liang B.C., Voroney R.P., Simard R.R., Donald R.G., Beyaert R.P. \& Martel J. (1997). Impact of tillage practices on organic carbon and nitrogen in cool, humid soils of eastern Canada. Soil Tillage Research 41: 191 - 201.

3. Baker K.F. (1976). The determination of organic carbon in soil using a probe-colorimeter. Laboratory Practice 25: 82 - 83.

4. Blake G.R. \& Hartge K.H. (1986). Bulk density. Methods of Soil Analysis, Part I. Physical and Mineralogical Agronomy Monograph no. 9, $2^{\text {nd }}$ edition (ed. A. Klute), pp. 363 - 375. American Society of Agronomy, Madison, USA.

5. Brookes P.C., Landman A., Pruden G. \& Jenkinson D.S. (1985). Chloroform fumigation and the release of soil nitrogen: a rapid direct extraction method to measure microbial biomass nitrogen in soil. Soil Biology and Biochemistry 17: 837 - 842 .

6. Campbell C.A., Biederbeck V.O., Zentner R.P. \& Lafond G.P. (1991). Effect of crop rotations and cultural practices on soil organic matter, microbial biomass and respiration in a thin black Chernozem. Canadian Journal of Soil Science 71: $363-376$.

DOI: http://dx.doi.org/10.4141/cjss91-035

7. Campbell C.A. \& Zentner R.P. (1993). Soil organic matter as influenced by crop rotations and fertilization in an aridic haploporoll. Soil Science Society of America Journal 57: $1034-1040$.

8. Ghani A.D., Dexter M. \& Perrott K.W. (2003). Hot water extractable carbon in soils, a sensitive measurement determining impacts of fertilization, grazing and cultivation. Soil Biology and Biochemistry 35: 1231 - 1243.

9. Hati K.M., Mandal K.G., Misra A.K., Ghosh P.K. \& Bandyopadhyay K.K. (2006). Effect of inorganic fertilizer 
and farmyard manure on soil physical properties, root distribution, and water-use efficiency of soybean in Vertisols of central India. Bioresource Technology 97: 2182 - 2188. DOI: http://dx.doi.org/10.1016/j.biortech.2005.09.033

10. Jenkinson D.S \& Ladd J.N. (1981). Microbial biomass in soil: measurement and turnover. Soil biochemistry, pp. 415 - 417 (eds. E.A. Paul \& J.N. Ladd), Decker Publishing, New York, USA.

11. Jinwei Z. \& Lianren Z. (2011). Combined application of organic and inorganic fertilizers on black soil fertility and maize yield. Journal of Northeast Agricultural University (English Edition) 18: 24 - 29.

12. Kumar B.M. (2011). Species richness and aboveground carbon stocks in the home gardens of central Kerala, India. Agriculture Ecosystem and Environment 140: 430 - 440. DOI: http://dx.doi.org/10.1016/j.agee.2011.01.006

13. Lal R. (2008). Carbon sequestration. Philosophical Transactions of the Royal Society B: Biological Sciences 363: $815-830$. DOI: http://dx.doi.org/10.1098/rstb.2007.2185

14. Lal R., Uphoff N., Stewart B.A. \& Hansen D.O. (2005). Climate Change and Global Food Security, pp. 778. Marcel Dekker/ Taylor and Francis, New York, USA.

15. Lal R., Follett R.F., Stewart B.A. \& Kimble J.M. (2007). Soil carbon sequestration to mitigate climate change and advance food security. Soil Science 172: 943 - 956. DOI: http://dx.doi.org/10.1097/ss.0b013e31815cc498

16. Lamb E.G., Kennedy N. \& Siciliano S.D. (2011). Effects of plant species richness and evenness on soil. Plant and Soil 338: $483-495$. DOI: http://dx.doi.org/10.1007/s11104-010-0560-6

17. Moore J.M., Klose S. \& Tabatabai M.A. (2000). Soil microbial biomass carbon and nitrogen as affected by cropping systems. Biology and Fertility of Soils 31: $200-210$. DOI: http://dx.doi.org/10.1007/s003740050646

18. Moormann F.R. \& Panabokke C.R. (1961). A new approach to the identification and classification of the most important soil groups of Ceylon. Soils of Ceylon, pp. 33 - 37. Department of Agriculture, Peradeniya.

19. Park D. (1976). Nitrogen level and cellulose decomposition by fungi. International Biodeterioration Bulletin 12: 85 - 99.

20. Pereira M.G., Loss A., Beutler S.J. \& Torres J.L.R. (2012). Granulometric and humic fractions carbon stocks of soil organic matter under no tillage systems in Uberaba, Brazil. Tropical and Subtropical Agroecosystems 15: 1 - 13.

21. Poirier V., Angers D.A., Rochette P., Chantigny M.H., Ziadi N., Tremblay G. \& Fortin J. (2008). Interactive effects of tillage and mineral fertilization on soil carbon profiles. Soil Science Society of America Journal 73: 255 - 261. DOI: http://dx.doi.org/10.2136/sssaj2008.0006

22. Puget P. \& Lal R. (2005). Soil organic carbon and nitrogen in a mollisol in Central Ohio as affected by tillage and land uses. Soil and Tillage Research 80: 201 - 213. DOI: http://dx.doi.org/10.1016/j.still.2004.03.018
23. Ratnayake R.R., Seneviratne G. \& Kulasooriya S.A. (2011). The effect of cultivation on organic carbon content in the clay mineral fraction of soils. International Journal of Soil Science 6: $217-223$.

DOI: http://dx.doi.org/10.3923/ijss.2011.217.223

24. Recous T.S., Bentz B., Line'res M., Che'neby D. \& Nicolardot B. (1995). Biochemical quality of crop residues and carbon and nitrogen mineralization kinetics under non-limiting nitrogen conditions. Soil Science Society of America Journal 64: 918 - 926.

25. SAS Institute (1999). SAS Institute Procedures in the SAS/STAT Guide for Personal Computers, version 6. SAS Institute Inc., Cary, USA.

26. Seneviratne G., Jayasekara A.P.D.A., De Silva M.S.D.L. \& Abeysekera U.P. (2011). Developed microbial biofilms can restore deteriorated conventional agricultural soils. Soil Biology and Biochemistry 43: 1059 - 1062.

DOI: http://dx.doi.org/10.1016/j.soilbio.2011.01.026

27. Singh K.P. \& Ghoshal N. (2007). Soil carbon in agroecosystems: issues and challenges. EnviroNews 13: $2-4$.

28. Six J., Frey S.D., Thiet R.K. \& Batten K.M. (2006). Bacterial and fungal contributions to carbon sequestration in agroecosystems. Soil Science Society of America Journal 70: $555-559$.

DOI: http://dx.doi.org/10.2136/sssaj2004.0347

29. Sparling G., Vojvodic-Vukovic M. \& Schipper L.A. (1998). Hot-water-soluble $\mathrm{C}$ as a simple measure of labile soil organic matter: the relationship with microbial biomass $\mathrm{C}$. Soil Biology and Biochemistry 30: 1469 - 1472.

30. Srinivasarao C.H., Venkateswarlu B., Lal R., Singh A.K., Kundu S., Vittal K.P.R., Balaguravaiah B., Vijaya Shankar Babu M., Chary G.R., Prasadbabu M.B.B. \& Reddy T.Y. (2012). Soil carbon sequestration and agronomic productivity of an Alfisol for a groundnut-based system in a semiarid environment in southern India. European Journal of Agronomy 43: 40 - 48.

DOI: http://dx.doi.org/10.1016/j.eja.2012.05.001

31. Uchidaa Y., Nishimurab S. \& Akiyamaa H. (2012). The relationship of water-soluble carbon and hot-watersoluble carbon with soil respiration in agricultural fields. Agriculture, Ecosystems and Environment 156: 116 - 122. DOI: http://dx.doi.org/10.1016/j.agee.2012.05.012

32. Vance E.D., Brookes P.C. \& Jenkinson D.S. (1987). An extraction method for measuring soil microbial biomass Carbon. Soil Biology and Biochemistry 19: 703 - 707.

33. Vandenbygaart A.J., Gregorich E.G. \& Angers D.A. (2003). Influence of agricultural management on soil organic carbon: A compendium and assessment of Canadian studies. Canadian Journal of Soil Science 83: 363 - 380. DOI: http://dx.doi.org/10.4141/S03-009

34. Weil R., Kandikar Islam K., Stine M., Joel Gruver J. \& SamsonLiebig S. (2003). Estimating active carbon for soil quality assessment: A simplified method for laboratory and field use. American Journal of Alternative Agriculture 18: 1 - 16. 